\title{
Attitude of Military and Paramilitary Officers towards the Role of Arabic Language in Addressing Security Issues in Nigeria
}

\author{
Musa Siddiq Abdullahi \\ Faculty of Education, \\ University of Ilorin, \\ Ilorin, Nigeria. \\ alfulaty2013@gmail.com
}

\author{
Musa Salisu \\ Faculty of Education, \\ University of Ilorin, \\ Ilorin, Nigeria. \\ salisumusa95@yahoo.com
}

\begin{abstract}
This study is a descriptive research that addresses the role of Arabic in handling security issues in Nigeria and the attitude of security officers towards this role. Arabic plays a significant role in addressing security challenges because it has the ability to solve problems between groups of people by ensuring an atmosphere of understanding and peaceful co-existence. The study's population consisted of all Nigerian military and paramilitary officers. Using stratified random sampling, 50 officers were selected from the Nigerian army, air force, police, and civil defense corporations in the North-east totaling 200 respondents altogether. One research question and one hypothesis guided the study. An "Arabic Language Education and National Security Questionnaire" questionnaire, with a reliability of 0.76 , was used to collect data. Descriptive statistics in the forms of frequencies and percentages were used to answer the research question, while one-way ANOVA was used to test the hypothesis at 0.05 significance level. The findings reveal a significant difference in the perceptions of Nigerian military and paramilitary officers regarding the role of Arabic in tackling security issues. It was recommended, among others that, the government recognize Arabic as a language equal in rank to English in Nigeria and utilize it as a medium of communication and instruction. The study suggests that Arabic be incorporated into the in-house training for military and paramilitary officers in charge of Nigerian national security.
\end{abstract}

Keywords: Nigerian national security, role of Arabic language, Arabic as a language of peace, Arabic for communication, military and paramilitary forces, security challenges in Nigeria

\section{INTRODUCTION}

Language is central to communication. It remains the most unique attribute of man, and enables man to function in various domains of human life. The issue of language is a very crucial and also usually a very controversial one in many nations of the contemporary world. Language is the one major factors that distinguishes between human and non-human animals. There is no other member of the animal kingdom that is able to use language for everyday communication the way human beings can. Indeed, there is no race or ethnic group that does not possess and use language. Otherwise, such a group would not qualify to be called humans (Ayodele, 2004). The importance 
of language in any field of human endeavor cannot be over-emphasized. This is because it is the medium through which thoughts and feelings are communicated. It is also a tool through which businesses are conducted and policies articulated and interpreted in governance. Language is used in arts, sciences, technology, philosophy and defense among other disciplines.

Arabic is the language of the Qur'an. Today, it is the most important language of the Semitic group spoken by millions of people and understood by many more. The Arabic writing system has an alphabet of twenty-eight consonants. Its writing system is from right to left and was introduced in Makkah not long before the revelation of the Qur'an (Galadanci, 1993). Among the Semitic family, Arabic language is perhaps the only one that has gallantly stood the test of time. It has gained a wide range of currency and leaves an indelible mark on the course of world history, culture and civilization (Hitti, 1976). It is on record that the West was able to recover major texts of Greek philosophy through their Arabic versions that were translated into Latin together with the summaries, commentaries and independent works of Arabic philosophy (Hourani, 1976). Furthermore, Arabic has been used to write scientific treatises like Chemistry, Alchemy, Algebra, Physics, Medicine, Astronomy, Geography, Optics and Mathematics (Sabra, 1976). Today, Arabic is a universally recognised language placed on equal pedestal with other international languages like English, French or German. It is a tool of political and diplomatic interactions within the United Nations Organization (UNO), the Africa Union (AU), and the Organisation of Petroleum Exporting Countries (OPEC) among other international languages (Ahmad, 2007; Oladosu, 1992).

In Nigeria, Arabic is known to have contributed immensely to the preservation of some aspects of the country's history, culture and language (Oladosu, 1992). It was well known to Nigeria before the European colonial conquest at the beginning of the $20^{\text {th }}$ century. The old Kanem/Bornu Empire, which was established as far back as the $9^{\text {th }}$ century A.D., was converted to Islam by the end of the $11^{\text {th }}$ century (Tukhan, 1975). With Arabic as its medium of transmission, Islam found its way gradually to other parts of the Northern states and from there to the South. By the middle of the $13^{\text {th }}$ century, Kanem had become an extensive empire and a center of Islamic civilization (Rudin, 1976).

Historically, Arabic is the oldest foreign language in Nigeria today. The reason is that its entry into the country dated back to the seventh century of the Christian era and the first century of the Hijrah calendar (Galadanci, 1993). Centuries before the advent of Europeans in Nigeria, Arabic had been used for religious, social and cultural purposes in northern Nigeria. It was in recognition of its significance that Arabic language was introduced into the Nigerian education curriculum as an academic discipline. In Nigeria today, three languages have been raised to the status of official languages. In addition to English, which is the nation's official language, Arabic and French are also taught in Nigerian schools as foreign languages (Mahmud, 2012 \& FRN, 2013).

Nigeria as a nation has a multiplicity of languages, cultures and religions. There are many Arabic schools in both northern and southern Nigeria. The number of students in these schools is so huge to the extent that their activities, attitudes and behaviors have a significant impact on the larger society (Abubakre, 1984). The emphasis on the search for knowledge by Islam explains the need of Arabic schools in Nigeria, for every Muslim at any point in time must have been a student of Islamic education. The reason is that the primary preoccupation of Muslims is not only to digest, but to grasp the contents as well as imports of Islam. This is achieved in institutions of learning 
known as Islamic schools (Abdullahi, 2005). The history of Arabic schools throughout the Arab world, and in the non-Arab world in particular, has been the history of the spread of Islam. Hence, Nigeria cannot be an exception for the history of these schools (the prophet's mosque, disciples' homes and shops for classes) which is as old as the advent of Islam itself (Galadanci, 1993).

In contrast, Arabic as a medium of instruction in formal education in Northern Nigeria plays very significant roles in areas such as social, political, economic and cultural among other activities before the introduction of English language. Northern Nigeria would have reached the level attained by the Arabized North African countries in their educational development, if chance had been accorded them to continue their educational pursuit through the Arabic medium (Galadanci, 1993). Arabic schools have continued to spring up and compete favorably with the English, this is because the average Nigerian Muslim, both in the North and South, prefers learning Arabic to English (Oladosu, 1992).

\section{Role of Language in the Issue of National and International Security}

The word "security" originates from the Latin word "Se-curus". "Se" means "without' and "curus" means "uneasiness". That implies that 'security' originally meant liberation from uneasiness, or a peaceful situation without any risks or threats. The English word "security" has a wider range of meaning including "to feel safe", and "to be protected", and is used to describe a situation without any risks or worries (Mesjasz, 2004). Security, according to the Oxford Advanced Learners Dictionary, means safety, freedom from danger or anxiety. Security is sometimes defined as the whole range of measures affecting the economic and social welfare of a population, as well as protection against internal or external aggressions. In the world today, the security of nations, societies and individuals is of great concern to all, as criminals have resorted to modern scientific methods in executing crimes against humanity.

The concept of 'security' generally is a crosscutting and multidimensional concept which has, over the last century, been the subject of great debate. Security has been seen as a situation where a person or thing is not exposed to any form of danger or risk of physical or moral aggression, accident, theft or deterioration. Some security experts argued that the concept of security has always been associated with the safety and survival of the state and its citizens from harm or destruction or from dangerous threats. The conception holds that the state is the only institution with the primary responsibility and power for the safety of its territory and its people (Zabadi, 2005). In addition, Omode (2011) see security as a dynamic condition which involves the relative ability of a state to counter threats to its core values and interest. McGrew (1988) holds that security of a nation hangs on two important pillars which are: (i) the maintenance and protection of socio-economic order in the face of internal and external threat; and (ii) the promotion of a preferred international order, which minimizes the threat to core values and interests, as well as to domestic order. Nwolise (2006) opined that security is an all-encompassing condition which suggests that a territory must be secured by a network of armed forces; that the sovereignty of the state must be guaranteed by a democratic and patriotic government, which in turn must be protected by the military, police and the people themselves.

Language is central to the existence of man. From early time, language has always been a communicative device, contributing to the development and growth of human societies. The ability to relate and harness his environment develops man's capacity to reorder his activities to an 
appreciable level, and has made language significant. Language has always played a vital role in confronting and mitigating security challenges, and protecting human lives and property. Studies (Cohen, 2001) have shown the ability of language to solve problems between people by creating the necessary atmosphere for understanding and peaceful resolution of differences. A breakdown of communication has often been responsible for misunderstanding in a society and among communities or nations that sometimes resulted in a full scale war.

\section{Statement of the Problem}

Language is crucial to solving conflicts and security issues. A case in point is the measure taken by American police who recruited four (4) Nigeria citizens into its intelligence and law enforcement units. The four Nigerians spoke Yoruba, the language used to address and mitigate crimes in the United State of America (USA), in lieu of the fact that many of the criminals arraigned were Yoruba speakers. A parallel can be drawn to the situation in Nigeria where Arabic can be used to mitigate security problems. Therefore, learning Arabic language by Nigerian security officers is vital. Since 1980, the Nigerian Army School of Education (NASE), through the Department of Arabic Language, has been doing well in this regard, but certainly more can be done. Arabic language will assist Nigerian military and paramilitary officers in peace keeping both nationally and internationally, especially in terms of understanding signals and intercepting communication, which will be of great importance (Ibrahim, 2013). In order to be able to render effective services to the country and her citizens nationally at all levels, there is a need to make Arabic the language of communication in Nigeria. However, the attitude of the officers in charge of national security in Nigeria towards learning Arabic as a measure to resolve conflicts and secure peace is not known. Therefore, understanding their attitude towards learning the language for mitigating security problems is a subject worthy of research.

\section{Research Purpose and Question}

The purpose of this study was to explore the attitude of Nigerian military and paramilitary officers towards Arabic as a language for peace and security and understand their attitude towards learning it for the purpose of addressing the national security issues in Nigeria. Thus, the research question posed was, "What is the attitude of Nigerian military and paramilitary officers towards the role of Arabic and learning the language in addressing insecurity in North-east Nigeria?"

\section{Research Hypothesis}

The following hypothesis was formulated and tested.

Ho1: There is no significant difference in the attitude of Nigerian military and paramilitary officers (i.e., army, air force, police and civil defense) towards the role of Arabic language in addressing insecurity in Northeast Nigeria and learning the language for this purpose. 


\section{METHODOLOGY}

\section{Research Design}

The design adopted for this study was a descriptive, cross-sectional survey design. It was considered appropriate by the researchers to give a systematic description of the role of Arabic language and national security in Nigeria.

\section{Instrument}

A self-developed questionnaire titled "Questionnaire on Arabic Education and National Security" was used in this study. The questionnaire comprised two sections: A and B. Section A of the questionnaire elicited information on the bio-data of the respondents, while Section B consisted of five (5) items measuring the attitude of the respondents towards using Arabic in addressing national security in Northeast Nigeria. The attitude items were structured along a 4-point Likerttype agreement scale ranging from "Strongly Agree" and "Agree," to "Strongly Disagree" and "Disagree."

\section{Population and Sample}

The ideal population for this study comprised all armed law enforcers in charge of national security in Northeast Nigeria. They comprised officers in four military and paramilitary categories: the army, air force, police and civil defense. The study's target population were security officers sent on the Joint Task Force (JTF) to the Northeast zone to curb Boko Haram in Nigeria. Purposive sampling technique was used to select 50 Muslim security officers in each category who spoke the Arabic Language. Thus, the proposed sample size for the study was 200 security officers, with 50 each from the army, air force, police and civil defense. Two hundred copies of the questionnaire were sent out, but twenty of these were either not returned or not properly filled out. Hence, the 180 that were properly filled out were used for the analysis.

\section{Data Collection and Analysis}

The researchers through four research assistants, one from each category of the sampled officers, administered the questionnaire forms to all the officers involved in the JTF operation. Each officer was given a copy of the questionnaire and one week to respond. The questionnaires were then manually collected from the respondents after one week.

The data gathered were analyzed using the following procedures: the demographic information of the respondents and data for research question 1 were addressed using descriptive statistics (frequencies and percentages), while ANOVA was used to test the hypothesis formulated. 


\section{RESULTS}

\section{Respondent Demographics}

Table 1 shows the ranks of officers and the number that participated in the study in frequencies and percentages. Forty-seven (47) army personnel in ten different ranks participated in the study, while forty-six (46) from the air force took part, in addition to forty-five (45) policemen and fortytwo (42) civil defense officers. They were about equal in number although there were slightly more army officers than officers in the other categories. The reason might be that the army are on ground to ensure peace and harmony within the country.

Table 1

Respondent Demographics $(\mathrm{N}=180)$

\begin{tabular}{|c|c|c|c|c|c|c|c|c|c|c|c|}
\hline \multicolumn{3}{|c|}{ Army } & \multicolumn{3}{|c|}{ Air Force } & \multicolumn{3}{|c|}{ Police } & \multicolumn{3}{|c|}{ Civil Defense } \\
\hline Rank & $\mathrm{N}$ & $\%$ & Rank & $\mathrm{N}$ & $\%$ & Rank & $\mathrm{N}$ & $\%$ & Rank & $\mathrm{N}$ & $\%$ \\
\hline Private & 5 & 10.6 & Sergeant & 7 & 15.6 & Corporal & 7 & 15.6 & $\begin{array}{c}\text { Corps } \\
\text { Asst. III }\end{array}$ & 8 & 19.0 \\
\hline $\begin{array}{l}\text { Lance } \\
\text { Corporal }\end{array}$ & 6 & 12.8 & Corporal & 6 & 13.0 & Sergeant & 7 & 15.6 & $\begin{array}{l}\text { Corps } \\
\text { Asst. II }\end{array}$ & 8 & 19.0 \\
\hline Corporal & 9 & 19.1 & $\begin{array}{l}\text { Warrant } \\
\text { Officer }\end{array}$ & 6 & 13.0 & Inspector & 8 & 17.8 & $\begin{array}{l}\text { Corps } \\
\text { Asst. I }\end{array}$ & 7 & 16.7 \\
\hline Sergeant & 9 & 19.1 & $\begin{array}{l}\text { Air Warrant } \\
\text { Officer }\end{array}$ & 6 & 13.0 & A S P I & 6 & 13.3 & AIC & 8 & 19.0 \\
\hline $\begin{array}{l}\text { Staff } \\
\text { Sergeant }\end{array}$ & 8 & 17.0 & Cadet & 5 & 10.9 & A S P II & 5 & 11.1 & IC & 6 & 14.3 \\
\hline $\begin{array}{l}2^{\text {nd }} \\
\text { Lieutenant }\end{array}$ & 3 & 6.4 & $\begin{array}{l}\text { Pilot } \\
\text { Officer }\end{array}$ & 4 & 8.8 & D S P & 4 & 8.9 & ASCI & 3 & 7.1 \\
\hline Lieutenant & 3 & 6.4 & $\begin{array}{l}\text { Sub Flying } \\
\text { Officer }\end{array}$ & 4 & 8.8 & S P & 3 & 6.7 & ASCII & 2 & 4.8 \\
\hline Captain & 2 & 4.3 & $\begin{array}{l}\text { Flight } \\
\text { Lieutenant }\end{array}$ & 3 & 6.5 & CSP & 2 & 4.4 & NILL & & \\
\hline Major & 1 & 2.1 & $\begin{array}{l}\text { Wing } \\
\text { Commander }\end{array}$ & 2 & 4.3 & $\mathrm{ACP}$ & 2 & 4.4 & NILL & & \\
\hline $\begin{array}{l}\text { Lieutenant } \\
\text { Colonel }\end{array}$ & 1 & 2.1 & $\begin{array}{l}\text { Group } \\
\text { Captain }\end{array}$ & 2 & 4.3 & DCP & 1 & 2.2 & NILL & & \\
\hline NILL & & & $\begin{array}{l}\text { Air } \\
\text { Commander }\end{array}$ & 1 & 2.2 & NILL & & & NILL & & \\
\hline Total & 47 & $100 \%$ & & 46 & $100 \%$ & & 45 & $100 \%$ & & 42 & $100 \%$ \\
\hline
\end{tabular}




\section{Attitude towards the Role of Arabic Language and Learning It for Security Purposes}

Table 2 shows the distribution of the officers' responses to the five items asked in the questionnaire.

Table 2

Attitude towards the Role of Arabic in Addressing Insecurity in Northeast, Nigeria $(\mathrm{N}=180)$

\begin{tabular}{llc}
\hline \multicolumn{1}{c}{ Items } & Agree & Disagree \\
\hline 1. Arabic language can help to reduce insecurity & 120 & 60 \\
& $(66.7 \%)$ & $(33.3 \%)$ \\
2. I am ready to learn Arabic language to boost my morale & 111 & 69 \\
in fighting insecurity & $(61.7 \%)$ & $(38.3 \%)$ \\
& & 44 \\
3. Incorporation of Arabic language into in-house training & 136 & $(24.5 \%)$ \\
$\quad \begin{array}{l}\text { for security officers will help to reduce insecurity in } \\
\text { Nigeria }\end{array}$ & $(75.6 \%)$ & 53 \\
I have the necessary capacity and plans to use Arabic in & 127 & $(29.5 \%)$ \\
curbing insecurity & $(70.6 \%)$ & 49 \\
Arabic as an international language will help in reducing & 131 & $(27.2 \%)$ \\
\hline
\end{tabular}

One hundred and twenty officers $(n=120)$ representing $66.7 \%$ agreed that Arabic as a language can help reduce insecurity; sixty officers $(n=60)$ representing $33.3 \%$ of the sample disagreed with this idea. This implied that a majority of the officers had a positive attitude towards Arabic as a language of security and were aware of its importance as an international language. This attitude and awareness are manifest in their response as a result of the experiences gained from the international operations they have participated in.

One hundred and eleven officers $(\mathrm{n}=111)$ or $61.7 \%$ agreed to being ready to learn Arabic to boost their morale in fighting insecurity. However, 38.3\% disagreed $(n=69)$, indicating an unwilling attitude to learn Arabic for the purpose combating insecurity in the country. The percentage that agreed with learning Arabic as a way of boosting their morale and techniques in fighting against insecurity is higher. This might be the result of their awareness of the benefits that await them when they understand Arabic Language.

Should Arabic language be incorporated into in-house training for security officers? One hundred and thirty-six officers $(\mathrm{n}=136)$ or $75.6 \%$ agreed that it should, showing a positive attitude and the right awareness of its role. About one fourth of the sample $(n=44 ; 24.5 \%)$ disagreed with the idea. This shows that the officers are aware of the relevance of Arabic language in talking insurgency within and outside the country. That explains why they welcome the inclusion of Arabic Language as an added advantage for the security officers during in-house training.

Do the officers have "the necessary capacity and plans to use Arabic in curbing insecurity?" One hundred and twenty-seven $(n=127)$ representing $70.6 \%$ reported that they did, while about a third $(29.5 \%, \mathrm{n}=53)$ said they did not have such a capacity or plans. This suggests that a majority see Arabic as capable of curbing insecurity. The last item in the questionnaire asked whether Arabic, as an international language, would help to reduce insecurity both nationally and internationally. To this 
item, one hundred and thirty-one $(n=131)$ representing $72.8 \%$ said yes, it would, while $27.2 \%$ ( $n$ $=49$ ) disagreed. This means a majority of the officers agreed that Arabic language has a global role to play in curbing insecurity. This implies the power that people see in language when it comes to peace making locally and internationally.

\section{Differences in Attitude by Officer Category}

The respondents represented four categories of officers: army, air force, police, and civil defense. To see if their attitudes towards the role of Arabic and learning the language for national and international security purposes would differ, a one-way Analysis of Variance (ANOVA) was run. The procedure was used to test the hypothesis postulated for this study at 0.05 level of significance

Ho1: There is no significant difference in the attitude of Nigerian military and paramilitary officers (i.e., army, air force, police and civil defense) towards the role of Arabic language in addressing insecurity in Northeast Nigeria and learning the language for this purpose.

The responses showing the respondents' attitude towards Arabic language were converted into continuous data and subjected to Levene's test of equality of variance before proceeding to the Analysis of Variance. The result of Levene's test is thus presented in Table 3.

Table 3

Test of Homogeneity of Variance $(\mathrm{N}=180)$

\begin{tabular}{rrrr}
\hline Levene Statistic & df1 & df2 & Sig. \\
\hline 2.732 & 3 & 176 & .117 \\
\hline
\end{tabular}

As revealed in Table 3, Levene's test showed that the variance obtained $(p=0.117)$ is greater than 0.05 alpha level. This shows that the population variances are equal $\left(\mathrm{F}_{(3,176)}=2.732 ; \mathrm{p}>0.05\right)$. In other words, the assumption of equal variance was met. Therefore, the analysis proceeded with interpreting the ANOVA results, shown in Table 4.

Table 4

Differences in Attitude towards Arabic Language among Nigerian Security Officers: One-Way ANOVA Results $(\mathrm{N}=180)$

\begin{tabular}{lcrrrr}
\hline & $\begin{array}{c}\text { Sum of } \\
\text { Squares }\end{array}$ & df & $\begin{array}{c}\text { Mean } \\
\text { Square }\end{array}$ & F & Sig. \\
\hline Between Groups & 204.047 & 3 & 68.016 & 19.037 & .001 \\
Within Groups & 628.814 & 176 & 3.573 & & \\
Total & 832.861 & 179 & & & \\
\hline
\end{tabular}

Note: $p$ value is significant at $<0.05$

As shown in Table 4, an F-value of 19.037 with a $p$-value 0.001 was obtained when computed at the 0.05 level of significance. Since the $p$-value of 0.001 is less than the 0.05 level of significance, the null hypothesis was rejected. In other words, there was a significant difference in the officers' attitude towards the role of Arabic language in addressing the issues of insecurity. To ascertain where the significant difference lay, Scheffe's post hoc test was carried out and the results are presented in Table 5. 
Table 5

Results of the Scheffe's Post-Hoc Analysis $(\mathrm{N}=180)$

\begin{tabular}{|c|c|c|c|c|c|c|}
\hline \multirow{3}{*}{$\begin{array}{l}\text { (I) } \\
\text { Security } \\
\text { Officers }\end{array}$} & \multirow{3}{*}{$\begin{array}{l}(\mathrm{J}) \\
\text { Security } \\
\text { Officers }\end{array}$} & \multirow{3}{*}{$\begin{array}{c}\text { Mean } \\
\text { Difference } \\
(\mathrm{I}-\mathrm{J})\end{array}$} & \multirow[b]{2}{*}{ Std. } & \multirow[b]{3}{*}{ Sig. } & \multicolumn{2}{|c|}{ 95\% Confidence Interval } \\
\hline & & & & & Lower Bound & Upper \\
\hline & & & Error & & & Bound \\
\hline \multirow[t]{3}{*}{ Army } & Air Force & .82979 & .39203 & .218 & -.2768 & 1.9364 \\
\hline & Police & $1.96312^{*}$ & .39422 & .000 & .8503 & 3.0759 \\
\hline & Civil Defense & $2.80598^{*}$ & .40135 & .000 & 1.6731 & 3.9389 \\
\hline \multirow[t]{3}{*}{ Air Force } & Army & -.82979 & .39203 & .218 & -1.9364 & .2768 \\
\hline & Police & $1.13333^{*}$ & .39631 & .046 & .0146 & 2.2520 \\
\hline & Civil Defense & $1.97619^{*}$ & .40341 & .000 & .8375 & 3.1149 \\
\hline \multirow[t]{3}{*}{ Police } & Army & $-1.96312^{*}$ & .39422 & .000 & -3.0759 & -.8503 \\
\hline & Air Force & $-1.13333^{*}$ & .39631 & .046 & -2.2520 & -.0146 \\
\hline & Civil Defense & .84286 & .40554 & .233 & -.3019 & 1.9876 \\
\hline \multirow[t]{3}{*}{ Civil Defense } & Army & $-2.80598^{*}$ & .40135 & .000 & -3.9389 & -1.6731 \\
\hline & Air Force & $-1.97619^{*}$ & .40341 & .000 & -3.1149 & -.8375 \\
\hline & Police & -.84286 & .40554 & .233 & -1.9876 & .3019 \\
\hline
\end{tabular}

Note: *The mean difference is significant at the 0.05 level.

The results in Table 5 show that statistically significant differences in attitude were detected between the army and police $(p=0.001)$ and civil defense $(p=0.001)$ with mean differences of 1.963 and 2.806 respectively. The mean difference (0.82979) in attitude towards Arabic language between the army and air force, however, is not significant $(p=0.218)$. Also, there were significant differences between the air force and police $(p=0.046)$, and the air force and civil defense $(p=$ $0.001)$. However, the mean difference $(0.84286)$ the police and civil defense is not significant $(p$ $=0.233$ ).

Thus, the significant differences in the respondents' attitude towards Arabic as a language for establishing national and international security occurred between the army and air force with mean scores of 9.83 and 9.00 respectively, and between the police and civil defense with mean scores of 7.89 and 7.02 , respectively.

In summary, the major findings of this study reveal that Arabic language was seen by most military and paramilitary officers as playing a vital role in addressing insecurity issues in Northeast Nigeria, and significant differences existed in their attitude and willingness to learn Arabic for national and international security purposes in the North East.

\section{DISCUSSION AND CONCLUSION}

The main focus of this study was to examine security officers' attitude towards the role of Arabic language in addressing insecurity issues in North-eastern Nigeria. The results indicate that most of the officers exhibited a positive attitude towards Arabic as a language for security and expressed a willingness to learn it for this purpose. They confirmed its vital role in addressing insecurity issues in Nigeria with $66.7 \%$ agreeing that Arabic as an international language can go a long way in tackling insecurity issues in the North East, in particular, and in Nigeria largely. This could be attributed to the respondents' experiences during their encounter with the Boko Haram militants, where most of the time, Boko Haram communicated in Arabic. This finding aligned with the 
submission of Mahmud (2012) and Ibrahim (2013) that international languages like Arabic play crucial roles in assisting the three major branches of Nigerian armed forces (the army, air force and navy) and other security forces to combat conflicts and aggression against Nigerians.

The second finding of the study revealed that $61.7 \%$ of the respondents are ready to learn Arabic language to enhance their morale and techniques in combating insecurity. This could be the result of deficiencies they felt when they could not understand Arabic when confronting militants who at times would communicate in Arabic to prevail over the security officers. This finding agreed with that of Ibrahim (2013) who found that Arabic Language could assist officers in peace making both nationally and internationally, especially when it comes to deciphering signals and intercepting communication.

The third finding of the study showed that $75.6 \%$ of the respondents agreed that incorporating Arabic language into the in-house training for security officers will help in reducing insecurity in Nigeria. The finding could also be attributed to the awareness of the security officers of the relevance of Arabic Language in fighting insurgencies within and outside the country. This finding corroborated the finding of Ibrahim (2013) who found that Arabic Language could assist officers in peace making both nationally and internationally, especially when it comes to understanding signals and intercepting communication. The implication of the aforementioned finding is the need to familiarize officers with basic Arabic knowledge so that they can read and understand Arabic text.

The fourth finding revealed that $70.6 \%$ of the respondents agreed that they have the necessary capacity and ability to use Arabic in curbing insecurity. This submission might be the result of their basic working knowledge of Arabic to improve their performance. The fifth finding

established that $72.8 \%$ of the respondents agreed that Arabic as an international language will help in reducing insecurity both nationally and internationally. This could be attributed to the power of language when it comes to peace making at local and international fronts. This finding aligned with the finding of Ibrahim (2013) who found that Arabic language could assist officers in global peace.

The last finding revealed that there were significant differences in the attitude and willingness to learn Arabic among Nigerian security officers. This finding is in line with Ibrahim (2013), Onifade (2013) and Jaja (2013) who found in their different studies that Arabic is particularly of a very high value to officers in the armed and security forces. The language will assist them nationally and internationally while in operations, especially in terms of deciphering signals, intercepting communication, and planning exigencies. From these findings, it is concluded that Arabic language and the learning of Arabic play a vital role in addressing insecurity issues in Nigeria.

The attitude of security officers was one that confirmed the instrumental role of Arabic language in curbing insurgencies in Nigeria. Security officers are ready to learn basic working knowledge of Arabic to improve the performance and success of their operations. Incorporating Arabic Language into in-house training for Nigeria's security forces will help to prepare them better for operations dealing with conflicts, aggression and peace restoration in Nigeria. Security officers have the capacity and ability to use Arabic in combating these issues of national and 
international security. Arabic as an international language could help in reducing insecurity both nationally and internationally.

\section{RECOMMENDATIONS}

Based on the research findings, the following recommendations are made:

The government at all levels should give more recognition to Arabic language as a medium of communication and/or instruction in Nigeria. The recognition should equal that given to the English language. This will go a long way in helping Nigerians to have a keen interest in understanding the language, not just for religious purposes, but also for the vital role of maintaining security in the country. Arabic language should be incorporated into in-house training for Nigeria's armed and security forces. This will create an awareness in these forces of the relevance of Arabic language in fighting insurgencies within and outside the country.

Adequate knowledge and skills of Arabic should be incorporated in the curricula of the Nigeria Defence Academy (NDA), Nigeria Police Academy (NPA) among other security forces and divisions. Religious bigotry should be shunned off to enable effective acquisition of Arabic language by the officers as an international language of communication.

\section{LIMITATION OF THE STUDY}

This study was a survey that utilized a simple 5-item questionnaire. A more in-depth understanding of the role of Arabic in ensuring peace and security in Nigeria and in combating forces like Boko Haram should be obtained from phenomenological research that utilizes interviews and focus group discussions.

\section{REFERENCES}

Abdullahi, M. S. (2005). Minaret of knowledge: az-zumratul adabiyyatul kamaliyyat. Ilorin: Jimhas Press.

Abubakre, R. D. (1984). The future of Arabic learning in Yoruba land. Ilorin Journal of Education, 4, 57-70.

Ahmad, M.K. (2007). The role of Arabic in Nigeria's foreign policy and economic relation with the Arabs. Journal of Studies in Language and Literature. 5(1), 1-10.

Ayodele, S.O. (2004). A description of varieties of Nigerian English for pedagogic purpose. British of Journal of Language Teacher, 21(2), 10-108.

Cohen, R. (2001). Language and conflict resolution: The limits of English. International Studies 
Review, 3 (1), 25-51. Retrieved from http://www.jstor.org/stable/3186511

Federal Republic of Nigeria (2013). National policy on education and 4-year strategic plan for the development of the education sector: 2011-2015 of professor Ruqayyatu Ahmed Rufa'i. NERDC Press, Yaba-Lagos: Nigeria.

Galadanci, S. A. S. (1993). Harakatul- lughatul- Arabiyyah wal- adabiyah fi Nijiriyah minas-Sanat 1804 ila Sanat 1966, Cairo: Darul- Ma'rif.

Hitti, P.K. (1979). Arab civilization: Language. New York: The Encyclopedia Americana Cooperation.

Hourani, G.F. (1976). Arab civilization: World legacy. New York: The Encyclopedia Americana Cooperation.

Ibrahim, A.I. (2013). The study of Arabic language in the Nigerian armed forces: Prospects and problems. International Journal of Bussiness and Social Science, 4(6), 189-195.

Jaja, C.N. \& Jude, O. (2013). Security and national development in Nigeria: The threat of Boko Haram. International Journal of Humanities and Social Sciences, 1(4), 285-291.

Mahmud, A.A. (2012). The Arabic Language: Its relevance to Nigerian development. European Scientific Journal, 8(26), 192-202.

Mesjasz, C. (2004, September). Security as an analytical concept. In 5th Pan-European conference on International relations, in The Hague (pp. 9-11).

Nwolise, O.B.C. (2006). National security and sustainable democracy. In Ojo, E.O. (Ed.). Challenges of sustainable democracy in Nigeria. Ibadan, Nigeria: John Archer Publishers.

Oladosu, A.G.A.S. (1992). The position of Arabic language in Nigerian schools today. Nigerian Journal of Foundations, 3(2), 181-190.

Omode, A.J. (2011). Nigeria: Analysing the security challenges of the Goodluck Jonathan administration. Canadian Social Science, 7(5), 90-102.

Onifade, C.A., Imhonopi, D., \& Urim, U.M. (2013). Addressing the insecurity challenge in Nigeria: The imperative of moral values and virtue ethics. Global Journal of Human Social Science, 13(2). Pp 52-62.

Rudin, H.R. (1976). Bornu, in Encyclopedia Americana 4, p.286.

Sabra, A.I. (1976). Arab Civilization: Position in Islamic world. The Encyclopedia Americana 2, New York: Americana Cooperation. p. 157.

Tukhan, I.A. (1976). Emaratun Al Barnu Al- I'slamiyyah. Bornu Islamic Empire. Cairo. 
Zabadi, S. (2005) Understanding security and security sector dynamics Baltimore: John Hopkins University Press. 